\title{
Evaluasi Pembelajaran Daring bagi Anak Berkebutuhan Khusus (ABK)
}

\author{
Nur Oktaviani ${ }^{1}$, Azza Tinri Setyono Putri ${ }^{2}$, Muklis Ari Nugroho ${ }^{3}$, Ratih Pratiwi ${ }^{4}$ \\ nurokta@student.ub.ac.id ${ }^{1}$, azzatsp_student.ub.ac.id², muklis_an@student.ub.ac.id ${ }^{3}$, \\ ratihpratiwi820@student.ub.ac.id ${ }^{4}$ \\ Universitas Brawijaya, Malang, Jawa Timur, Indonesia
}

Keywords: Online Learning, Children with Special Needs (CSN), Covid-19 Pandemic

Kata Kunci: Pembelajaran Daring, Anak Berkebutuhan Khusus (ABK), Pandemi Covid-19

\section{ABSTRACT}

During the current pandemic, it is necessary to always stay at home to prevent an increase in virus transmission, so distance learning is one solution that is quite appropriate to do so that educational services, especially for children with special needs, can continue. This research was conducted using a literature study method by reading various reading sources relevant to the research topic. The purpose of this study was to explore the implementation, experience, problems and advantages and disadvantages of distance learning for children with special needs (CSN). The results showed that during the pandemic all learning activities for children with special needs were carried out online. From the implementation of online learning, there are several obstacles experienced such as the lack of learning tools, learning media that cannot be accessed by all CSNs, online learning is more difficult for children with special needs to understand, online learning facilities are incomplete, and CSN parental skills are lacking. It is hoped that after this pandemic, teachers and related parties provide training to parents of children with special needs so that they have good competence and skills in accompanying children when studying, so that later parents will not depend on teachers alone. In addition, related parties are expected to pay more attention to the education of children with special needs by providing the facilities they need in the learning process, especially in distance learning.

\section{ABSTRAK}

Dimasa pandemi saat ini mengharuskan untuk selalu berada dirumah agar mencegah peningkatan penularan virus, maka pembelajaran pembelajaran jarak jauh merupakan salah satu solusi yang cukup tepat untuk dilakukan agar pelayanan pendidikan khususnya pada anak berkebutuhan khusus dapat terus berlangsung. Penelitian ini dilakukan dengan metode studi literatur dengan membaca berbagai sumber bacaan yang relevan dengan topik penelitian. Tujuan dari penelitian ini adalah untuk menggali mengenai pelaksanaan, pengalaman, permasalahan serta kelebihan dan kekurangan selama pembelajaran jarak jauh pada anak berkebutuhan khusus (CSN). Hasil penelitian menunjukkan bahwa selama pandemi berlangsung seluruh kegiatan pembelajaran pada anak berkebutuhan khusus dilakukan secara daring. Dari pelaksanaan pembelajaran daring ini terdapat beberapa kendala yang dialami seperti kurangnya perangkat pembelajaran, media belajar yang tidak dapat diakses oleh semua CSN, pembelajaran online lebih sulit dipahami oleh anak berkebutuhan khusus, fasilitas pembelajaran daring yang kurang lengkap, dan keterampilan orangtua CSN yang kurang. Diharapkan setelah pandemi ini, guru dan pihak terkait memberikan pelatihan kepada orangtua anak berkebutuhan khusus agar mereka memiliki kompetensi dan keterampilan yang baik dalam mendampingi anak ketika belajar, sehingga nantinya orangtua tidak bergantung kepada guru saja. Selain itu, pihak terkait diharapkan untuk lebih memperhatikan pendidikan anak berkebutuhan khusus dengan memberikan fasilitas yang dibutuhkan mereka dalam proses pembelajaran, khususnya pada pembelajaran jarak jauh. 


\section{PENDAHULUAN}

Pada penghujung tahun 2019 lalu, muncul sebuah wabah virus yang dinamakan Coronavirus Disease-19 (covid-19) yang pertama kali ditemukan di Kota Wuhan, China. Virus ini dengan cepat menyebar ke berbagai Negara di seluruh dunia yang akhirnya membuat WHO menyatakan Virus Covid19 ini sebagai sebuah pandemi. Di Indonesia sendiri kasus pertama virus Covid-19 yang terkonfirmasi muncul pada awal Maret 2020 sebanyak 2 kasus. Mengutip dari Kementerian Kesehatan Indonesia (2020) virus ini dapat menular melalui percikan batuk/bersin (droplet). Para ahli kesehatan selanjutnya merekomendasikan tindakan untuk mencegah penularan virus ini dengan rajin mencuci tangan, menjaga jarak, dan juga selalu memakai masker.

Dengan adanya kasus positif Covid-19 ini, Indonesia mengambil langkah cepat untuk menghentikan penyebarannya. Melalui Surat Edaran Mendikbud No 4 Tahun 2020 tentang Pelaksanaan Kebijakan Pendidikan dalam Masa Darurat Penyebaran Covid-19. Surat Edaran tersebut selanjutnya digunakan sebagai dasar untuk melaksanakan pembelajaran dari rumah atau pembelajaran jarak jauh (PJJ). Pembelajaran jarak jauh atau PJJ merupakan sebuah pendekatan yang dilakukan dalam proses pembelajaran dimana siswa dan guru berada di tempat yang terpisah namun tetap dapat berinteraksi dengan aktif melalui media teknologi yang disediakan (Kaplan dalam Tanduklangi dan Amri, 2019). Pembelajaran jarak jauh ini merupakan salah satu pelayanan yang diberikan oleh Pemerintah di bidang pendidikan, agar peserta didik tetap dapat melaksanakan pembelajaran meskipun sedang berada di rumah masing-masing. Pembelajaran ini merupakan sebuah hak bagi seluruh peserta didik tak terkecuali anakanak berkebutuhan khusus (ABK) sehingga meskipun dalam kondisi darurat seperti pandemi ini, pembelajaran tetap akan dilakukan meskipun secara jarak jauh. Menurut McVey (2008), Pembelajaran jarak jauh ini memiliki kelebihan dan kelemahannya masing-masing.Kelebihan dari adanya pembelajaran jarah jauh ini adalah adanya fleksibilitas, aksesibilitas yang mudah, menciptakan lingkungan belajar yang mandiri dan waktu yang lebih bermanfaat. Sedangkan untuk kelemahan dari pembelajaran jarah jauh ini adalah hilangnya hak peserta didik yang motivasi dan disiplin yang rendah dalam belajar, hal ini dipengaruhi bagaimana guru dapat membuat pembelajaran yang bermakna selama PJJ ini.

Dalam pembelajaran jarak jauh ini, guru harus mampu membangun interaksi dan ikatan yang erat dengan peserta didik agar pembelajaran yang dilakukan dapat interaktif. Menurut Cavanaugh (2006), Pembelajaran jarah jauh yang interaktif dapat dilakukan menggunakan beberapa metode seperti, chat, telepon, audio conference, video conference, ataupun broadcast audio dan video. Pembelajaran jarak jauh pada anak berkebutuhan khusus atau ABK bergantung peran orang tua dalam mendampingi proses pembelajaran selama di rumah baik mengenai penggunaan teknologi maupun sebagai perantara anak dengan guru. Menurut Cavanaugh (2006), keberhasilan dari pembelajaran jarah jauh ini dipengaruhi oleh beberapa faktor seperti keterampilan yang dimiliki anak dalam belajar dan komunikasi, beradaptasi terhadap penggunaan teknologi, keterampilan mengaitkan materi pembelajaran dengan contoh kasus yang relewan dan juga keterampilan dalam mencari sumber belajar yang sesuai. Keterampilanketerampilan yang telah dijelaskan oleh Cavanaugh tersebut menjadi sebuah pemasalahan tersendiri bagi anak berkebutuhan khusus atau ABK. Sebagai contoh, pada anak anak penyandang autisme mereka akan kesulitan dalam berkomunikasi dan berinteraksi dengan orang lain sedangkan komunikasi menurut Cavanaugh merupakan salah satu faktor penentu dalam pembelajaran jarak jauh tersebut. Oleh karena itu peran orang tua atau pendamping anak berkebutuhan khusus dalam menjalani proses pembelajaran jarak jauh sangatlah penting mengingat proses pembelajaran pada anak berkebutuhan khusus (ABK) bukan hanya bertujuan meningkatkan kemampuan akademiknya saja melainkan juga untuk meningkatkan perkembangan mentalnya. Bukan hanya itu saja, keadaan emosional anak berkebutuhan khusus yang tidak stabil juga akan mempengaruhi proses pembelajaran selama di rumah. Oleh karena itu, sangat dibutuhkan kemampuan dan keterampilan khusus dalam mendampingi anak berkebutuhan khusus dalam belajar.

Tantangan dalam proses pembelajaran anak berkebutuhan khusus tidaklah sedikit, terutama jika dilakukan menggunakan metode pembelajaran jarak jauh (PJJ). Baik orangtua maupun guru memiliki peran yang sangat penting di masa pandemi Covid19 ini. Guru harus bisa menciptakan suasana belajar jarak jauh yang menyenangkan dan bermakna bagi 
anak berkebutuhan khusus, sedangkan orangtua harus memiliki kesiapan serta keterampilan dasar dalam mendampingi anaknya ketika belajar. Berdasarkan hal tersebut, tujuan dari penelitian ini adalah untuk mengetahui dan mengevaluasi pelaksanaan pembelajaran jarak jauh pada anak berkebutuhan khusus (ABK) serta menilai kesiapan strategi dalam menghadapi pembelajaran jarak jauh. Sedangkan maksud dari penelitian ini adalah untuk menggali mengenai pelaksanaan, pengalaman, permasalahan serta kelebihan dan kekurangan selama pembelajaran jarak jauh pada anak berkebutuhan khusus (ABK).

\section{LANDASAN TEORI}

Pembelajaran daring merupakan salah satu metode pembelajaran online yang dilaksanakan secara jarak jauh antara pendidik dan peserta didik dengan jaringan internet (Mustofa, dkk, 2019). Menurut Kuntarto (2017), pembelajaran daring merupakan pembelajaran yang dapat mempertemukan peserta didik dan guru untuk melaksanakan interaksi pembelajaran dengan menggunakan bantuan internet. Abidin, dkk (2020) mengemukakan bahwa media yang digunakan dalam pembelajaran daring dapat berupa aplikasi online seperti google classroom, zoom, google meet, dan whatsapp yang dapat memungkinkan pendidik dan peserta didik untuk dapat melakukan kegiatan belajar mengajar tanpa adanya interaksi secara langsung di kelas dengan perolehan materi dari pendidik berupa power point, video, dan e-book. Pembelajaran daring ini tidak hanya diterapkan pada anak-anak normal pada umumnya, tetapi juga dapat diterapkan pada anak-anak yang memiliki kebutuhan khusus. Direktorat Pendidikan Luar Biasa dalam Erawati (2016) menyatakan bahwa Anak Berkebutuhan Khusus (ABK) merupakan anak yang secara signifikan memiliki penyimpangan atau kelainan, baik secara fisik, mental-intelektual, sosial, emosi, maupun dalam proses tumbuh kembangnya apabila dibandingkan dengan anak normal seusianya sehingga Anak Berkebutuhan Khusus (ABK) ini memerlukan layanan khusus. Thomson (2010:2) mengemukakan bahwa anak dikatakan memiliki kebutuhan khusus apabila mereka mengalami kesulitan dalam belajar yang jauh lebih besar jika dibandingkan dengan anakanak seusia mereka dan memiliki ketidakmampuan yang dapat menghambat atau menghalangi mereka untuk menggunakan berbagai fasilitas pendidikan yang telah disediakan.

\section{METODE PENELITIAN}

Penelitian ini disusun dengan menggunakan metode studi literatur atau penelitian kepustakaan. Studi literatur ini dilaksanakan dengan cara membaca berbagai sumber yang relevan dengan topik terkait guna memperoleh data-data yang diperlukan dalam penelitian ini. Penelitian studi literatur adalah cara penelitian yang menggunakan berbagai referensi atau sumber rujukan yang terancang secara ilmiah yang meliputi pengumpulan bahan referensi yang berkaitan dengan tujuan penelitian. Teknik pengumpulan data dengan metode kepustakaan, dan mengintegrasikan serta menyajikan data.

Penelitian studi literatur adalah penelitian yang menggunakan kumpulan informasi dan data yang diperoleh dari sumber seperti dokumen, buku, artikel, majalah, berita, dan sebagainya. Artikel yang disajikan sumber dalam penelitian ini terkait pembelajaran daring di masa pandemi untuk anak berkebutuhan khusus. Penelitian ini bertujuan untuk mengetahui bagaimana pembelajaran pada anak berkebutuhan khusus mulai dari apakah efektif; strategi yang digunakan; serta implikasinya pada masa pandemi COVID 19.

\section{HASIL PENELITIAN DAN PEMBAHASAN}

\section{Penyelenggaraan Pembelajaran Daring bagi Anak Berkebutuhan Khusus (ABK)}

Semenjak munculnya pandemi COVID-19, berbagai upaya telah dilakukan oleh pemerintah demi memutus rantai penyebaran virus ini yakni salah satunya adalah dengan menerapkan adanya physical distancing tak terkecuali pun pada bidang pendidikan yang pada akhirnya memberikan dampak dalam mengubah sistem pembelajaran yang mulanya bertatap muka di dalam ruangan kelas secara drastis harus diubah menjadi sebuah pembelajaran di dalam jaringan (daring) atau pembelajaran jarrah jauh dari rumah. Fenomena ini tentunya menjadi sebuah tantangan tersendiri bagi peserta didik, tenaga pendidik, dan juga orang tua. Terlebih lagi mereka adalah peserta didik dengan kebutuhan khusus atau peserta didik ABK, dimana perlu adanya dukungan dan kerjasama yang aktif dari tenaga pendidik serta orang tua dalam kegiatan belajar mengajarnya agar pembelajaran dapat tersampaikan dengan baik dan efektif, mengingat bahwa di dalam kelas inklusif ini memiliki peserta didik berkebutuhan khusus yang beragam. 
Pembelajaran daring adalah sebuah metode pembelajaran yang dapat mempertemukan tenaga pendidik dengan peserta didik untuk tetap dapat melaksanakan kegiatan belajar mengajar dengan menggunakan bantuan teknologi dan internet. Lebih jelasnya lagi, pembelajaran daring ini merupakan pembelajaran yang menggunakan rangkaian peralatan elektronik beserta adanya jaringan internet dengan aksesibilitas, konektivitas, fleksibilitas, serta kemampuan untuk memunculkan berbagai jenis interaksi pembelajaran demi menyampaikan materi pembelajaran, interaksi, serta bimbingan. Dengan menggunakan internet dan teknologi multimedia dalam kegiatan belajar mengajar mampu mengubah cara penyampaian pelajaran atau pengetahuan serta dapat menjadi salah satu alternatif pembelajaran yang biasanya dilaksanakan melalui tradisional dengan bertatap muka di dalam satu ruangan kelas yang sama, kini pembelajaran jarak jauh tanpa mengenal ruang dan waktu.

Penyelenggaraan pembelajaran daring ini dapat dilakukan dengan memanfaatkan gabungan dari berbagai jenis sumber belajar yang terkait dengan materi pembelajaran. Rigianti (2020) mengatakan sumber belajar tersebut menjadi modal yang utama dalam mendukung pengembangan pembelajaran secara daring ini. Penggunaan berbagai sumber belajar, diharapkan dapat membuat pembelajaran menjadi lebih menarik dan dapat sesuai dengan karakteristik serta kebutuhan pembelajaran peserta didik sehingga tujuan pembelajaran yang diharapkan dapat tercapai. Berbagai sumber belajar tersebut dapat berupa dokumen (ebook), gambar, video, dan audio. Sumber belajar tersebut dapat digunakan oleh peserta didik sebagai bahan belajar dengan melihat dan membacanya. Menurut (Abidin et al., 2020), media yang digunakan dalam pembelajaran daring ini berupa aplikasi online, yaitu Google Classroom yang memungkinkan guru serta peserta didik untuk dapat mengikuti pembelajaran tanpa melalui tatap muka secara langsung di ruang kelas dengan pemerolehan materi pembelajaran berupa power point, e-book, dan video. Terdapat juga aplikasi pembelajaran online yang memungkinkan kita untuk melakukan Video Conference, seperti Google Meet dan Edmodo. Selain itu, guru, orang tua, dan peserta didik juga dapat menggunakan aplikasi WhatsApp untuk berkomunikasi dan mengirimkan berbagai macam tugas dalam pembelajaran dengan berbagai format, seperti Microsoft Word, Microsoft Power Point, pdf, foto (jpg), link video, pesan suara, bahkan video call. Guru sebagai tenaga pendidik juga dapat mengarahkan peserta didik untuk memanfaatkan portal rumah belajar yang disediakan oleh Kemendikbud melalui siaran televisi dan radio sebagai salah satu sarana penunjang pembelajaran daring (Rigianti, 2020).

Pada setiap jenjang pendidikan dilaksanakan metode pembelajaran jarak jauh, tak terkecuali untuk sekolah inklusi, tentu saja di sekolah inklusi ini terdapat berbagai anak dengan kebutuhan khusus yang mana di setiap pertemuan tatap muka saja mereka memerlukan perhatian khusus. Dalam pembelajaran jarak jauh ini juga begitu, anak berkebutuhan khusus di sekolah inklusi tetap harus memerlukan perhatian khusus. Dalam melaksanakan pelaksanaan pembelajaran daring ini peserta didik bukan hanya perlu beradaptasi namun tetap harus meneruskan pembelajaran atau program yang telah dilaksanakan sebelumnya, tidak mudah memang namun dengan adanya bantuan dan bimbingan dari guru pembelajaran ini dapat terlaksana dengan baik. Untuk peserta didik berkebutuhan khusus selain melaksanakan pembelajaran sesuai dengan materi yang tentunya sudah di modifikasi, peserta didik juga harus melaksanakan program pembelajaran individu.

Pembelajaran daring yang dilakukan oleh peserta didik berkebutuhan khusus di sekolah inklusi membutuhkan dampingan dan bimbingan dari orang tua, dan keluarga lainnya yang tentu saja harus mampu mengakses internet dengan luas. Menurut Ahsani (2020), dalam menerapkan pembelajaran daring, orang tua sangat berperan penting dalam proses belajar peserta didik dalam pembelajaran daring di rumah ini. Meski demikian, hal tersebut tidak menjanjikan keefektifan peserta didik mampu memahami materi dengan baik, terlebih lagi peserta didik yang bersekolah di sekolah inklusi. Peserta didik dengan kebutuhan khusus yang bersekolah di sekolah inklusi ini memiliki hambatan yang beragam, yakni adanya perbedaan pada masingmasing peserta didik mulai dari perbedaan bakat, kemampuan, minat, dan kebutuhannya. Oleh karena itu, pelayanan pendidikan yang diberikan haruslah sesuai dengan kebutuhan masing-masing peserta didik.

Kolaborasi dan kerjasama antara orang tua dengan tenaga pengajar sangat diperlukan untuk mengurangi berbagai hambatan dan kendala yang timbul dalam proses pelaksanaan pembelajaran daring ini. Jika pada saat pembelajaran tatap muka, segala sesuatu yang telah disampaikan oleh tenaga pengajar di sekolah akan ditindak lanjuti atau 
diteruskan oleh orang tua mereka di rumah, maka pada saat pembelajaran daring ini orang tua lah yang akan mendampingi peserta didik berkebutuhan khusus dalam proses belajarnya di sekolah yang kemudian langsung ditindak lanjuti oleh mereka di rumah. Orang tua menjadi pegangan utama selama pelaksanaan pembelajaran jarak jauh oleh peserta didik berkebutuhan khusus ini. Pembelajaran daring terhadap anak berkebutuhan khusus tentunya menyesuaikan kondisi dari peserta didik itu sendiri, Ada beberapa strategi yang dilakukan oleh sekolah inklusi dalam menerapkan pembelajaran daring bagi peserta didik berkebutuhan khusus mereka. Beberapa strategi pelaksanaan pembelajaran daring bagi peserta didik berkebutuhan khusus adalah sebagai berikut:

a. Strategi Pengajaran yang di Indivisualisasikan Program ini merupakan sebuah strategi yang digunakan oleh lembaga sekolah untuk mengenali dan mengintegrasi pendidikan sesuai dengan individu yang bersangkutan. Dalam strategi ini, tenaga pengajar yakni guru harus menyesuaikan materi pembelajaran yang diberikan dengan kemampuan peserta didik berkebutuhan khusus sehingga mereka mampu berinteraksi dengan minat mereka masing-masing.

b. Strategi Kooperatif

Pembelajaran dengan strategi kooperatif ini dimaksudkan bahwa dimana peserta didik mampu terdorong untuk dapat bekerja sama dalam kelompok kecil pada tugas akademik. Strategi kooperatif ini dapat membuat peserta didik memiliki rasa semangat, kekeluargaan, dan keakraban dengan para tenaga pengajar dan lingkungan sekitarnya sehingga mereka tidak mudah bosan.

c. Strategi Modifikasi Tingkah Laku

Modifikasi tingkah laku ini ialah sebuah aplikasi sistematis dari adanya prinsip-prinsip dan teknik-teknik belajar untuk dapat mengukur dan meningkatkan perilaku seorang individu dalam rangka membantunya agar dapat berfungsi secara penuh di dalam masyarakat. Tujuan strategi ini ialah mengurangi atau menghilangkan tingkah laku tidak baik.

Ketiga strategi di atas adalah strategi yang diterapkan oleh sekolah-sekolah inklusi dalam rangka pelaksanaan pembelajaran jarak jauh. Penggunaan strategi tersebut dengan konteks yang inovatif agar dapat membuat pelajaran tidak membosankan bagi para peserta didik. Dan melalui strategi-strategi di atas, tenaga pengajar mampu membuat media pembelajaran yang menarik sebagai alat untuk menyampaikan isi materi pembelajaran dengan memanfaatkan adanya teknologi. Dengan adanya penggunaan media pembelajaran, harus mampu untuk menyajikan pesan pembelajaran yang jelas dan dapat mengembangkan kemampuan peserta didik dalam memahami materi-materi yang disampaikan oleh tenaga pengajar. Dalam pelaksanaan pembelajaran daring yang dilakukan oleh sekolah inklusi tersebut, ada beberapa aspek juga yang perlu diperhatikan seperti program bermakna, komunikasi, pengembangan diri, modifikasi pengajaran, modifikasi kurikulum, dan fleksibel. Jadi, proses pelaksanaan pembelajaran daring bagi anak berkebutuhan khusus ini haruslah disesuaikan dengan kebutuhan kondisi dari peserta didik itu sendiri, orang tua serta tenaga pengajar harus saling bekerja sama untuk mampu mendampingi anak-anak berkebutuhan khusus mengikuti pembelajaran daring agar materi dapat tersampaikan dengan baik. Namun, di dalam pelaksaannya pun masih ditemukan berbagai kendala dan hambatan yang menyebabkan peserta didik ini menjadi tertinggal.

\section{Perbandingan Pelaksanaan Sekolah Inklusi- Sekolah Luar Biasa Sebelum Pandemi dengan Pelaksanaan di Masa Pandemi (PJJ)}

Sebagaimana telah dijelaskan sebelumnya, strategi-strategi yang telah disusun oleh tenaga pengajar yakni guru pada sekolah inklusi di masa pandemi yakni pembelajaran daring (dalam jaringan) atau kerap dikenal pembelajaran jarak jauh, strategi-strategi yang telah ditetapkan cukup untuk dijadikan dasar acuan pelaksanaan dari pembelajaran jarak jauh atau daring di masa pandemi covid-19 dewasa ini. Akan tetapi, lain halnya dengan pembelajaran jarak jauh pada sekolah inklusi yakni sekolah luar biasa untuk anak berkebutuhan khusus yang dimana membutuhkan konsentrasi ekstra baik oleh tenaga pengajar maupun orang tua pendamping buah hatinya yang merupakan anak berkebutuhan khusus. Strategi yang telah ditetapkan dapat menjadikan faktor pendukung jalannya pembelajaran daring sekolah inklusi di masa pandemi, akan tetapi dalam aplikatifnya strategi-strategi yang telah disusun tersebut tidak 
dapat menandingi keefektifan dari proses pembelajaran tatap muka pada masa sebelum pandemi berlangsung. Hal ini dapat diketahui berdasar pada studi literatur dengan hasil penelitian terdahulu yakni penelitian oleh mahasiswa ITS (2021) dalam penjelasannya pada "Permasalahan Kegiatan Belajar Mengajar Jarak Jauh Bagi Siswa Berkebutuhan Khusus" yang menjelaskan bahwa berdasar hasil quesioner yang dilakukan, pembelajaran daring tetap dinilai tidak efektif dikarenakan menemui banyak kendala dan berdampak pada hasil belajar siswa berkebutuhan khusus yang cukup memprihatinkan. Sehingga, tenaga pengajar sekolah inklusi tetap melakukan pembelajaran dengan metode home visit yakni mendatangi rumah anak berkebutuhan khusus tersebut untuk didampingi dan melakukan pembelajaran secara inklusif.

Atas dasar tersebut, antara pembelajaran daring atau pembelajaran jarak jauh dengan pembelajaran tatap muka sebagaimana mestinya lebih efektif menggunakan pembelajaran tatap muka. Meskipun kebijakan proses pembelajaran di Indonesia di masa genting yaitu pada masa covid-19 dilakukan secara online, akan tetapi tetap saja untuk sekolah inklusif bagi anak berkebutuhan khusus tenaga pengajar tetap harus mendampingi secara langsung dengan model pembelajaran home visit yang dimana tentu akan membutuhkan tenaga pengajar ekstra dikarenakan setiap satu siswa di dampingi oleh satu tenaga pengajar dan hal ini tentunya sangat tidak efektif apabila dilakukan secara berkelanjutan. Sekolah inklusif pada masa pembelajaran tatap muka atau offline jauh lebih efektif yang dimana dapat dilihat pada beberapa dampak atas pemberlakuan pembelajaran dengan metode jarak jauh atau daring sebagaimana berikut:

1) Kurangnya antusiasme siswa berkebutuhan khusus dalam mengikuti pembelajaran lewat media online

2) Perkembangan prestasi belajar siswa berkebutuhan khusus semakin menurun disebabkan orang tua tidak dapat mendampingi dengan sempurna sebagaimana tenaga pengajar yang biasa memberikan materi dengan profesional kepada siswa berkebutuhan khusus

3) Siswa berkebutuhan khusus cenderung terdistraksi apabila melakukan pembelajaran dengan media online dan semakin tidak dapat berkonsentrasi dengan baik sebagaimana mestinya

4) Siswa berkebutuhan khusus tidak dapat beradaptasi dengan metode pembelajaran yang cenderung lebih susah dimengerti sebab tidak dapat berinteraksi secara langsung dengan guru mereka

Berdasar hal tersebut bahwasannya jika dibandingkan dengan pembelajaran secraa tatap muka yang dimana siswa berkebutuhan khusus (ABK) dapat berinteraksi langsung dengan guru mereka dan tentunya guru akan dapat membina, membimbing, dan juga mengembangkan tingkat kreativitas siswa secara langsung akan terkendala dikarenakan pemberlakuan pembelajaran dengan metode daring atau jarak jauh di masa pandemi dewasa ini. Tentunya, apabila dilakukan secara berkelanjutan pembelajaran online pada sekolah inklusi ini, maka akan menimbulkan dampak yang lebih serius bagi perkembangan anak berkebutuhan khusus (ABK).

\section{Hambatan-Hambatan Pelaksanaan Kegiatan Belajar Mengajar pada Masa Pandemi}

Dimasa pandemi covid-19 sebagaimana berdasar pada keputusan Kementerian pendidikan, bahwasannya sekolah diselenggarakan secara daring atau online termasuk pada sistem kegiatan belajar mengajar pada sekolah inklusi bagi anak berkebutuhan khusus (ABK) atau sekolah luar biasa di Indonesia. Akan tetapi dalam keberlangsungannya, proses belajar mengajar dengan sistem daring atau online bagi anak berkebutuhan khusus ini tidak efektif dan tidak efisien ketika dilaksanakan. Dalam pelaksanaannya diketemukan beberapa kendala dan/atau hambatan yang dimana sangat mempengaruhi potensi keberhasilan dari proses pembelajaran online dimasa pandemi covid-19. Hambatan-hambatan tersebut yaitu diantaranya:

1) Siswa berkebutuhan khusus (ABK) tidak seluruhnya memiliki perangkat yang mendukung untuk proses kegiatan belajar mengajar dengan metode online, sehingga tenaga pengajar tetap menggunakan metode tatap muka dengan mengunjungi rumah siswa tersebut (metode home visit) yang dinilai sangat tidak efektif

2) Penggunaan media pembelajaran online dengan menggunakan zoom, google meet,dll 
hanya dapat diakses oleh sebagian siswa berkebutuhan khusus saja dikarenakan siswa dengan disabilitas tertentu seperti tunarungu dan tunawicara akan sangat terhambat dan tidak dapat melakukan pembelajaran dengan sistem online tersebut

3) Metode belajar pada kegiatan belajar mengajar online akan lebih sulit dimengerti dan dipahami oleh siswa berkebutuhan khusus dikarenakan siswa tidak dapat mengembangkan potensi kreativitas mereka sebagaimana mestinya dikarenakan terbatas pada media online

4) Modul berupa e-book dan sarana pembelajaran lainnya yang khusus diperuntukkan untuk siswa berkebutuhan khusus masih kurang memadai baik dari kesiapan maupun ketersediannya terutama pada berbagai kebutuhan siswa yang memiliki disabilitas berbeda-beda

5) Perbedaan karakteristik setiap siswa yang menjadi kendala dilaksanakannya pembelajaran jarak jauh

6) Perkembangan siswa berkebutuhan khusus dalam aspek sosial yakni berinteraksi dengan teman sebaya dan guru akan sangat terhambat dengan pemberlakuan pembelajaran online, serta;

7) Hambatan dari segi orang tua siswa berkebutuhan khusus yang belum sepenuhnya memberikan dukungan penuh kepada anaknya saat belajar di rumah.

Hambatan-hambatan tersebut kerap kali diketemukan dalam pelaksanaan pembelajaran daring atau online pada siswa berkebutuhan khusus yang dimana hambatan tersebut tidak hanya berasal dari sisi siswa berkebutuhan khusus saja akan tetapi juga dari sisi orang tua dan serta tenaga pengajar yang sulit dalam menyesuaikan pembelajaran dengan metode jarak jauh yang utamanya harus menyesuaikan dengan kebutuhan masing-masing siswa berkebutuhan khusus.

Upaya Mengatasi Hambatan-Hambatan dalam Pelaksanaan Kegiatan Belajar Mengajar bagi Anak Berkebutuhan Khusus

Pelaksanaan kegiatan belajar mengajar pada Anak Berkebutuhan Khusus (ABK) tidak terlepas dari adanya berbagai hambatan yang dihadapi.
Dalam hal ini, ada beberapa upaya yang dapat dilakukan agar kegiatan belajar mengajar pada peserta didik yang memiliki berkebutuhan khusus dapat dilaksanakan secara maksimal. Upaya-upaya tersebut, antara lain:

1) Untuk peserta didik berkebutuhan khusus yang tidak memiliki perangkat mendukung dalam proses kegiatan belajar mengajar dengan metode pembelajaran daring yakni pemerintah maupun pihak sekolah dapat membantu peserta didik tersebut dengan memberikan bantuan berupa perangkat pendukung seperti smartphone agar peserta didik tersebut dapat mengikuti kegiatan pembelajaran daring dan tidak tertinggal pelajaran yang disampaikan oleh guru

2) Untuk peserta didik berkebutuhan khusus yang mengalami tunarungu atau tunawicara, maka peserta didik tersebut dalam mengikuti kegiatan pembelajaran secara daring dapat didampingi oleh orang tua, yang mana orang tua disini dapat membantu menjelaskan kepada anaknya terkait materi yang disampaikan oleh guru, sehingga tidak hanya guru saja yang berperan dalam pembelajaran daring ini, tetapi orang tua juga berperan untuk mendampingi anaknya dalam proses pembelajaran. Sebagaimana yang disampaikan Subarto (2020) bahwa orang tua mempunyai peran penting dalam membangun regulasi diri dan penguatan pada anak selama belajar di rumah

3) Untuk peserta didik berkebutuhan khusus yang mengalami kesulitan dalam memahami materi pembelajaran yang disampaikan, maka guru dapat memberikan materi pembelajaran berupa modul maupun video, yang mana dalam video tersebut terdapat subtitle agar peserta didik, khususnya peserta didik yang mengalami tuna rungu dapat memahami materi yang diberikan dengan membaca subtitle yang ada dalam video tersebut.

4) Upaya yang dapat dilakukan untuk mengatasi hambatan terbatasnya modul atau $e$-book yang diperuntukkan bagi peserta didik berkebutuhan khusus yaitu guru tidak hanya dapat memberikan materi berupa modul tetapi juga dapat memberikan materi yang sesuai dari video-video yang ada di youtube untuk menambah sumber referensi. 
5) Upaya yang dapat dilakukan untuk mengatasi perbedaan karakteristik setiap peserta didik yakni dalam proses pembelajaran peserta didik berkebutuhan khusus dapat dikelompokkan sesuai dengan kebutuhannya, sehingga dengan begitu kemungkinan besar karakteristik yang dimiliki setiap peserta didik akan sama.

6) Untuk mengatasi peserta didik yang terhambat dalam berinteraksi dengan guru maupun teman sebayanya dikarenakan pemberlakuan pembelajaran jarak jauh yaitu dalam menjelaskan materi pembelajaran, guru tidak hanya memberikan modul atau video saja, tetapi guru juga perlu menjelaskan materi dengan menggunakan platform zoom atau goole meet agar peserta didik dapat berinteraksi langsung dengan guru dan peserta didik lainnya. Untuk mengatasi hal ini, guru juga dapat memberikan tugas kelompok kepada para peserta didik, yang mana dengan begitu antara peserta didik yang satu dengan peserta didik yang lain akan lebih banyak berinteraksi untuk mengerjakan tugas yang diberikan. Selain itu, dalam seminggu sekali peserta didik dengan didampingi oleh orang tua dapat mengumpulkan tugas-tugas yang diberikan olah guru, sehingga peserta didik dapat berinteraksi secara langsung dengan guru dan teman-temannya.

7) Untuk mengatasi hambatan dari segi orang tua peserta didik berkebutuhan khusus yang belum sepenuhnya memberikan dukungan penuh kepada anaknya saat pembelajaran daring, maka pihak sekolah perlu melakukan sosialisasi kepada para orang tua peserta didik berkebutuhan khusus terkait pentingnya peran orang tua dalam pendidikan anaknya. Selain itu, perlu adanya kesadaran orang tua bahwa anak berkebutuhan khusus memang membutuhkan pendampingan, khususnya dalam kegiatan pembelajaran yang dilakukan secara daring.

Kompetensi dan keterampilan dalam mendidik dan mendampingi anak berkebutuhan khusus, penting untuk dimiliki oleh guru dan orang tua. Selain itu, guru dan orang tua peserta didik berkebutuhan khusus harus terus aktif dan kooperatif dalam mengikuti pelatihan-pelatihan yang dapat meningkatkan kompetensi dan keterampilannya dalam mendidik dan mendampingi peserta didik yang memiliki kebutuhan khusus. Pihak sekolah juga perlu memberikan pelatihan kepada guru dan para orang tua terkait penggunaan teknologi agar dapat menggunakan platform pendukung pada saat pelaksanaan pembelajaran daring. Dengan upayaupaya tersebut diharapkan dapat mengatasi hambatan-hambatan yang ada sehingga pelaksanaan pembelajaran daring bagi anak berkebutuhan khusus dapat berjalan secara efektif.

\section{KESIMPULAN}

Selama pandemi Covid-19 ini, seluruh peserta didik melaksanakan pembelajaran melalui jarak jauh atau daring. Pembelajaran jarak jauh yang dilakukan pada anak berkebutuhan khusus (ABK) masih belum maksimal karena mengalami banyak hambatan atau kendala diantaranya adalah tidak semua anak berkebutuhan khusus memiliki perangkat yang mendukung, media belajar yang tidak dapat diakses oleh semua ABK dikarenakan penyandang disabilitas tertentu, pembelajaran online akan lebih sulit dipahami oleh anak berkebutuhan khusus, fasilitas dan sarana pembelajaran daring yang kurang lengkap, serta kemampuan dan keterampilan orangtua $\mathrm{ABK}$ yang kurang dalam mendampingi anaknya ketika belajar daring. Meskipun disebagian sekolah inklusi sosialisasi kepada orangtua anak berkebutuhan khusus sebelum pembelajaran jarak jauh ini dilaksanakan sudah diberikan, namun pada realitanya belum sepenuhnya terealisasikan dengan baik sehingga pembelajaran jarak jauh yang dilaksanakan pada sekolah insklusi masih belum dapat dikatakan efektif pelaksanaannya. Oleh karena itu, baik orangtua maupun guru seharusnya memiliki kemampuan dan keterampilan yang mumpuni dalam mendampingi anak berkebutuhan khusus ketika belajar terutama dalam pembelajaran jarak jauh ini, khususnya dalam mengakses teknologi. Diharapkan setelah pandemi ini, diberikan pelatihan kepada orangtua anak berkebutuhan khusus agar orangtua memiliki kompetensi dan keterampilan yang baik dalam mendampingi anak ketika belajar, sehingga nantinya orangtua tidak hanya bergantung kepada guru saja. Selain itu, bagi pihak terkait diharapkan untuk bisa lebih memperhatikan pendidikan anak berkebutuhan khusus (ABK) dengan memberikan fasilitas atau sarana dan prasarana yang dibutuhkan mereka dalam proses pembelajaran, khususnya pada pembelajaran jarak jauh. 


\section{DAFTAR PUSTAKA}

Abidin, Z. dkk. (2020). Pembelajaran Online Berbasis Proyek Salah Satu Solusi Kegiatan Belajar Mengajar Di tengah Pandemi Covid-19. Jurnal Ilmiah Profesi Pendidikan, 5(1), 64 - 70.

Cavanaugh, C. 2006. Distance Learning. In N. J. Salkind (Ed), Ensyclopedia of Human Development (Vol. 1, pp. 382-383). Thousand Oaks, CA: SAGE Reference.

Dewi, N. P. dkk. (2020). Problematika Pembelajaran untuk Anak Berkebutuhan. Jurnal Pendidikan Inklusi. 04, 001-010.

Erawati. (2016). Pendidikan Karakter Bangsa pada Anak Berkebutuhan Khusus dalam Pendidikan Inklusi. Universitas Lampung.

Hamidaturrohmah, H., \& Mulyani, T. (2020). Strategi Pembelajaran Jarak Jauh Siswa Berkebutuhan Khusus di SD Inklusi Era Pandemi Covid-19. Elementary: Islamic Teacher Journal, 8(2).

Kementerian Kesehatan RI. 2020. Pedoman Pencegahan Dan Pengendalian Coronavirus Disease (Covid19). Jakarta: Direktorat Jenderal Pencegahan dan Pengendalian Penyakit.

Kementerian Pendidikan dan Kebudayaan. 2020. Surat Edaran Mendikbud No. 4 Tahun 2020 Tentang Pelaksanaan Kebijakan Pendidikan Dalam Masa Darurat Covid-19. Jakarta : Kemendikbud.

Kuntarto, E. (2017). Keefektifan Model Pembelajaran Daring dalam Perkuliahan Bahasa Indonesia di Perguruan Tinggi. Journal Indonesian Language Education and Literature, 3(1), 99-110.

McVey, M. H. 2008. Distance Learning. In N. J. Salkind \& K. Rasmussen (Eds.), Encyclopedia of Educational Psychology (Vol.1, pp. 261-267). Thousand Oaks, CA: SAGE Publications.

Mustofa, M., Chodzirin, M., \& Syekti, L. (2019). Formulasi Model Perkuliahan Daring Sebagai Upaya Menekan Disparitas Kualitas Perguruan Tinggi. Walisongo Journal of Information Technology, I(2), 151-160.

Sadikin, A., \& Hamidah, A. (2020). Pembelajaran Daring di Tengah Wabah Covid-19:(Online Learning in the Middle of the Covid-19 Pandemic). Biodik, 6(2), 214-224.

Sandi, Elisabeth D. (2020). 3 Strategi Atasi Tantangan PJJ Anak Berkebutuhan Khusus. Diakses pada 12 Desember 2021 pukul 21.00 dari https://edukasi.kompas.com/read/2020/11/05/ 111443271/3-strategi-atasitantangan-pjianak-berkebutuhan-khusus

Setia, B., dkk. (2020). Pengalaman Belajar Daring Siswa Berkebutuhan Khusus Pada Pandemi Covid-19 di SD Inklusif. Jurnal IAIN Kudus, Vol.08.
Sheposh, R. 2020. Coronavirus 2019 (COVID-19). Salem Press Encyclopedia of Health.

Subarto. (2020). Momentum Keluarga Mengembangkan Kemampuan Belajar Peserta Didik Di Tengah Wabah Pandemi Covid-19. Adalah: Buletin Hukum dan Keadilan, 4 (1), 13-18.

Tanduklangi, A \& Amri, C. 2019. Manajemen Sumber Daya Pembelajaran Bahasa Berbantuan Komputer: Computer Assisted Language Learning. DeePublish: Yogyakarta. 